\title{
INTRODUCTION TO THE SYMPOSIUM ON INTERSTATE DISPUTES OVER WATER RIGHTS
}

\author{
Gabriel Eckstein ${ }^{*}$ and James Salzman ${ }^{* *}$
}

Disagreements over the management and allocation of transboundary freshwater resources have become increasingly prominent in international relations. Serious diplomatic tensions surround management of the Jordan, Mekong, Nile, Rio Grande, Silala, Syr Darya and Amu Darya, and Tigris and Euphrates rivers, to name just the most prominent examples among the world's more than three hundred shared watercourses. Nor is there any reason to think tensions will subside in the future.

In many parts of the world, demand for freshwater already exceeds accessible supplies. ${ }^{1}$ Water use globally has more than tripled since the 1950s, growing at more than double the rate of population growth over the same time period. ${ }^{2}$ Over the next thirty years, global demand is expected to increase by another 20 to 30 percent. ${ }^{3}$ These basic realities heighten the potential for disagreements and conflicts between riparian states.

Such disputes can escalate into larger regional conflicts. In the Aral Sea Basin, the discord between Tajikistan and Uzbekistan over the Rogun Dam has raised concerns over broader regional destabilization and even interstate violence. Disagreement over the Xayaburi Hydropower Project (XHP) on the Mekong River, albeit contested with less rhetoric than the Rogun confrontation, has made many observers fear for the stability and the economic development of mainland Southeast Asia. And recent confrontations between Afghanistan and Iran have led to the outbreak of local violence and occasionally strained relations between the two states in an already fragile region.

Despite mounting tensions among states, armed conflicts over transboundary freshwater have remained relatively limited to date. Yet growing water needs and dwindling supplies, climate change, shifting developmental and environmental priorities, and other concerns are straining cross-border hydro relations. Whether disagreements over shared freshwater resources will continue to be resolved peacefully will depend, in part, on the viability, durability, and flexibility of international law to prevent and resolve such disputes.

This symposium examines the role and relevance of international water law (IWL) for peacefully resolving disputes over transboundary freshwater resources. Taken together, the essays provide an impressive breadth of approaches, from close examination of contemporary disputes over transboundary freshwater resources to the interpretation and application of specific IWL norms and principles. We are fortunate, as well, to feature the perspectives of scholars from Africa, Asia, Europe, and North America.

\footnotetext{
* Professor of Law and Director of the Energy, Environmental \& Natural Resources Systems Law Program, Texas A\&M University School of Law, Forth Worth, Texas, United States.

** Donald Bren Distinguished Professor of Environmental Law, UCLA Law School, Los Angeles, California, United States, \& UCSB Bren School of Environmental Science and Management, Santa Barbara, California, United States.

${ }^{1}$ Alberto Boretti \& Lorenzo Rosa, Reassessing the Projections of the World Water Development Report, 1-2 nPJ CleAn Water 1 (2019).

${ }^{2}$ Mervyn Piesse et al., Global Water Supply and Demand Trends Point Towards Rising Water Insecurity, Future Directions InT'L (Feb. 27, 2020).

3 Boretti \& Rosa, supra note 1, at 15.
}

(C) Gabriel Eckstein and James Salzman 2021. This is an Open Access article, distributed under the terms of the Creative Commons 170 Attribution licence (http://creativecommons.org/licenses/by/4.0/), which permits unrestricted re-use, distribution, and reproduction in any medium, provided the original work is properly cited. 
In the opening essay, Susanne Schmeier, from the Institute for Water Education at IHE Delft in the Netherlands, addresses the guiding role of international water law principles as diplomats seek to resolve shared watercourse conflicts. ${ }^{4}$ The traditional focus on IWL principles, she argues, emphasizes their roles in legal adjudication and enforcement. Since so few conflicts are ever subject to adjudication processes, however, this overlooks the arguably even more important function of IWL principles as guiding negotiations. The essay's main insight is that IWL principles play dual roles-both setting the framework for negotiations and serving as the subject of negotiations themselves. While this creates an "inherent dilemma," since the legal principles themselves become the contested substance of the negotiations, she argues that the use of IWL principles in such deliberations have a positive lawmaking impact, strengthening the legal regime governing shared watercourses.

Francesco Sindico from Strathclyde Law School in Scotland, focuses on the role of international water law in the face of deeply contested transboundary water conflicts. ${ }^{5}$ The tension between national sovereignty and transboundary water cooperation is inescapable yet must be managed effectively. Sindico frames this tension by exploring the no harm rule and the equitable and reasonable utilization principle. Moving from theory to practice, he grounds his analysis by asking whether Turkey could dam the Tigris and Euphrates, Brazil over-pump the Guarani Aquifer System, or Egypt pressure upstream Nile states to keep them from developing water infrastructure.

Salman M.A. Salman, former Lead Counsel and Water Law Adviser at the World Bank, takes a close look at the competing principles of equitable and reasonable utilization, on the one hand, and the obligation against causing significant harm, on the other. ${ }^{6}$ It is no surprise that, in practice, lower riparians tend to emphasize the no harm rule while upper riparians focus on the reasonable utilization principle. The essay provides an enlightening history of the principles' drafting and subsequent development from 1911 through today. Salman concludes by calling for development of a treaty creating basin management organizations with broad and meaningful mandates to enhance cooperation.

Mara Tignino, Reader at the University of Geneva Faculty of Law, examines prior notification and consultation. ${ }^{7}$ This norm is now an accepted principle of international law, but much remains unclear in its application. Tignino provides a valuable explanation of the different aspects of the principle in practice- the threshold for providing notification, what constitutes timely notification, adequate content, and subsequent consultation and negotiation. Indeed, she argues that prior notification and consultation of projects that risk transboundary harm constitute customary norms binding on both upstream and downstream countries. The process of notification goes beyond merely state-to-state communication, but to local communities, as well, though this has not yet reached the status of a customary norm.

Dinara Ziganshina, the Deputy Director of the Scientific Information Center of Interstate Commission for Water Coordination in Central Asia considers the impressively diverse roles that the over 120 river commissions have played over the past two centuries in managing shared watercourses. ${ }^{8}$ Drawing from examples around the world, from the Congo and Scandinavia to the Mekong and Aral Sea, she argues that river commissions have helped prevent, manage and solve cross-border water disputes by creating epistemic communities of water experts, laying a foundation for shared technical understanding, and adapting over time. The essay is realistic,

\footnotetext{
${ }^{4}$ Susanne Schmeier, International Water Law Principles in Negotiations and Water Diplomacy, 115 AJIL UnBound 173 (2021).

${ }^{5}$ Francesco Sindico, National Sovereignty Versus Transboundary Water Cooperation: Can You See International Law Reflected in the Water?, 115 AJIL UnBound 178 (2021).

${ }^{6}$ Salman M.A. Salman, Equitable and Reasonable Utilization and the Obligation Against Causing Significant Harm-Are they Reconcilable?, 115 AJIL Unbound 183 (2021).

${ }^{7}$ Mara Tignino, Prior Notification and Water Rights, 115 AJIL Unbound 189 (2021).

${ }^{8}$ Dinara R. Ziganshina, Institutional Mechanisms for Preventing and Resolving Cross-Border Water Disputes, 115 AJIL UnBound 195 (2021).
} 
acknowledging that many difficulties remain, most notably through limited resources and inadequate authority to meet contemporary challenges.

The symposium concludes with an essay by Gabriel Eckstein from the Texas A\&M University School of Law and co-editor of this Symposium. ${ }^{9}$ Given the large number and breadth of shared groundwater resources-twice as many transboundary and shared aquifers as surface waters - as well as the importance of groundwater as the primary source of water in many parts of the world, surprisingly little law and scholarship exists on the issue. Because groundwater poses quite different types of management challenges than surface water, it may well require a different legal regime, yet the first treaty focusing on shared groundwater appeared only in the late 1970s. The essay explains the history and current status of shared groundwater law (scant though it may be) and identifies the features that future law will need to address. The essay provides an important road map for an area of international water law that will surely grow in importance in the coming decades.

The diverse essays in this Symposium illustrate that the international law applicable to transboundary freshwater resources is at once expansive and focused. While covering a broad array of topics and scenarios, from negotiation and data sharing to norm creation and litigation, it is also quite narrowly tailored to address the singular resource of freshwater in specific settings. As developed as the regime may be, the essays make clear that it must continue to evolve and react to changing circumstances, such as climatic variability, growing demand, and increased knowledge about freshwater resources.

Water is one of the few truly essential requirements for life. Thus, it is no surprise that disagreements among nations over this precious resource will continue and likely grow in the coming years. Nevertheless, it is important to keep in mind that water management has more often been a source of cooperation than of conflict. ${ }^{10}$ And while conflicts have certainly occurred, the vast majority of disputes have been resolved peaceably and in accordance with international law treaties and norms. Despite many challenges, international water law remains a vital and often effective guide for nations as they seek to resolve difficult and important water allocation disputes.

${ }^{9}$ Gabriel Eckstein, International Law for Transboundary Aquifers: A Challenge for Our Times, 115 AJIL Unbound 201 (2021).

10 Aaron Wolf et.al., Managing Water Conflict and Cooperation, in 2005 State of the World: Redefining Global Security 80-95 (Worldwatch Inst. 2005); Boretti \& Rosa, supra note 1. 